\title{
Germination of Eugenia brasiliensis, E. involucrata, E. pyriformis, and E. uniflora (Myrtaceae) under water-deficit conditions ${ }^{1}$
}

\author{
Mariane Cristina Inocente ${ }^{2 *}$, Claudio José Barbedo ${ }^{2}$
}

\begin{abstract}
This work aims at evaluating the tolerance of seeds of Eugenia brasiliensis Lam., E. involucrata DC., E. pyriformis Camb., and E. uniflora L. (Myrtaceae) to water deficit. Germination was carried out in polyethylene glycol 6000 solutions, at different osmotic potentials $(0.0,-0.5,-1.0,-1.5,-2.0,-3.0,-4.0$, and $-5.0 \mathrm{MPa})$. The seeds were also placed in trays containing sand as substrate, and the water was replenished at different times, for up to 34 days. Seeds were evaluated as for their ability to undergoing a deficit period, and of germinating when water was made available again. In general, Eugenia spp. seeds were able to germinate at up to $-1.5 \mathrm{MPa}$. In water potentials lower than $0.0 \mathrm{MPa}$, the beginning of germination experienced a delay, and it became better distributed throughout time. In the trays, the water restriction for up to 16 days did not limit normal seedling development. Seeds of Eugenia spp. were considerably tolerant to water deficit, as for both intensity and duration, which guarantees the development of seedlings and the propagation of the species.
\end{abstract}

Index terms: resistance to drought, water restriction.

\section{Germinação de sementes de Eugenia brasiliensis, E. involucrata, E. pyriformis e E. uniflora (Myrtaceae) submetidas a condição de déficit hídrico}

\begin{abstract}
RESUMO - Este trabalho foi realizado com o objetivo de avaliar a tolerância ao déficit hídrico de sementes de Eugenia brasiliensis Lam., E. involucrata DC, E. pyriformis Camb. e E. uniflora L. (Myrtaceae). As sementes foram colocadas para germinar em soluções de polietilenoglicol 6000 com diferentes potenciais osmóticos $(0,0,-0,5,-1,0,-1,5,-2,0,-3,0,-4,0$ e $-5,0$ $\mathrm{MPa}$ ). Elas também foram postas em bandejas contendo areia como substrato, com reposição de água em diferentes períodos, por até 34 dias. Também foi avaliada a capacidade das sementes passarem por déficits hídricos e germinarem quando houvesse disponibilidade hídrica. Em geral, as sementes de Eugenia spp. foram capazes de germinar em até -1,5 MPa. Em potenciais hídricos menores que 0,0 MPa, houve atraso no início da germinação e maior distribuição ao longo do tempo. Nas bandejas, a restrição hídrica de até 16 dias ainda permitiu o desenvolvimento de plântulas normais. Sementes de Eugenia spp. mostraramse muito tolerantes aos déficits hídricos, tanto em relação à intensidade quanto à duração, assim garantindo o desenvolvimento das plântulas e a propagação das espécies.
\end{abstract}

Termos para indexação: resistência à seca, restrição hídrica.

\section{Introduction}

Water deficit is one of the most common environmental stresses faced by plants, and also the most influential factor in the germinative process (Stefanello et al., 2006; Rego et al., 2011). For germination to take place, enough available water in the surroundings is necessary to activate the chemical reactions related to the metabolism, so that the embryo can continue its development.

Especially at the beginning of imbibition, water potentials that are too negative tend to limit imbibition, thus preventing the events of the germinative process from occurring normally, and possibly leading to the death of the embryo (Stefanello et al., 2006). When seeds undergo a period of water shortage, the water potential of the cells decreases, consequently reducing the turgor potential, which compromises cell expansion and

${ }^{1}$ Submitted on $08 / 17 / 2018$. Accepted for publication on 11/05/2018.

${ }^{2}$ Instituto de Botânica, Núcleo de Pesquisa em Sementes, 04301-902 - São Paulo, SP, Brasil.

*Corresponding author $<$ mariane.inocente@gmail.com $>$ 
development, as well as its metabolism (Jaleel et al., 2009). Therefore, such condition inhibits the hypocotyl and primary root growth, even though the seeds are still metabolically active, and consequently prompt to germinate (Santos et al., 2011).

The capacity of germinating under water stress has ecological advantages for some species, related to the delay of the phenomena. Once germination becomes better distributed along a more extended period, seedlings have a higher probability of finding favorable environmental conditions to establish themselves and grow (Fanti and Perez, 2004; Rosa et al., 2005).

The genus Eugenia, belonging to the Myrtaceae family, is among the most popular species employed in urban landscaping, commercial fruit production (in natura or industrially processed), and medicine making (SchmedaHirschmann et al., 1987). Once seeds of Eugenia are sensitive to desiccation, their extended storage is generally not recommended (Delgado and Barbedo, 2012). Even though they are dispersed with high initial water content, they might face field conditions which are adverse to seedling development, such as xeric periods, in which water availability in the soil is a limiting factor that can cause stress.

The present work aimed at verifying the ability of different species of Eugenia of tolerating water-deficit conditions.

\section{Material and Methods}

Ripe fruits (with the typical coloration of each species) of Eugenia brasiliensis Lam., E. involucrata DC., E. pyriformis Camb., and E. uniflora L. were harvested in October and November 2017, at Fontes do Ipiranga State Park, located in São Paulo city, Brazilian state of São Paulo - 23³8'S; $46^{\circ} 37^{\prime} \mathrm{W}$; $785 \mathrm{~m}$ altitude.

The fruits were picked from three (E. brasiliensis), two (E. involucrata), four (E. pyriformis), and three (E. uniflora) matrices. To do so, the soil surrounding each tree crown was covered with a plastic mesh, and all dispersed fruits were collected daily, for approximately seven consecutive days. After harvested, the fruits were immediately taken to the laboratory, where a preliminary selection was performed, in which fruits that happened to be too immature, or had been damaged by birds, insects, or microorganisms were discarded.

The seeds were manually removed from the fruits with the aid of a sieve, under running water. After being washed, they were placed on a filter paper, so the excess of residual water on the surface could be blotted. Next, they were packed in polyethylene-made, perforated plastic bags and stowed at $10^{\circ} \mathrm{C}$, until the moment of use (no more than seven days).

The seeds were characterized as for their water content (expressed in wet bases percentage), through the oven method at $103 \pm 3{ }^{\circ} \mathrm{C}$ for 17 hours (ISTA, 2017). The water potential (in MPa) was also gauged with a WP4 Dewpoint Potentiometer (Decagon Devices, Pullmann, USA). In these trials, four replications were performed, each with ten seeds cut in half.

Aqueous solutions of polyethylene glycol 6000 (PEG) at different concentrations were prepared for testing the osmotic potential conditions of 0.0 (pure water, used as the control), $-0.5,-1.0,-1.5,-2.0,-2.5,-3.0,-3.5,-4.0,-4.5,-5.0,-5.5,-6.0$, $-6.5,-7.0,-7.5,-8.0,-8.5,-9.0,-9.5$, and $-10.0 \mathrm{MPa}$, according to methodology proposed by Michel and Kaufmann (1973). Aliquots of $1.92 \mathrm{~mL}$ were analyzed with the potentiometer, straight from the containers, or over $0.433 \mathrm{~g}$ of germination paper cut in $2.5 \mathrm{~cm}$ discs. For every osmotic potential concentration, four replications were performed.

Seeds from the four species were sown in paper rolls (four replications with 16 seeds each), moistened with water (0.0 MPa) or PEG solutions at different concentrations to promote the osmotic potentials of $-0.5,-1.0,-1.5,-2.0,-3.0$, -4.0 , and $-5.0 \mathrm{MPa}$. The rolls were packed in plastic bags, and then incubated inside a germination chamber at $25^{\circ} \mathrm{C}$, under continuous white-light illumination. Every week, for 60 days, seed status was assessed, and those presenting radicle with at least 2.0-mm length were considered germinated. The normal seedling formation of E. brasiliensis and E. pyriformis was also evaluated, according to the guidelines of Delgado and Barbedo (2012).

By the end of the experiment, the non-germinated seeds in each treatment were sorted into two groups. Seeds in group 1 were maintained under a water-deficit condition; whereas seeds in group 2 were rinsed so they could be totally cleansed of any PEG solution residues, and then placed in a water-moistened substrate. The final analysis was carried out after 30 days.

Seeds of the four species were germinated inside gerboxes $(11.0 \mathrm{~cm} \times 11.0 \mathrm{~cm} \times 3.5 \mathrm{~cm})$ containing sand moistened with water. Due to their variation in size, E. pyriformis seeds were divided into two groups: the small (from 0.5 to $1.0 \mathrm{~cm}$ ) and the large ones (from 1.0 to $2.0 \mathrm{~cm}$ ).

Initially, the empty gerboxes were individually weighed with an analytical scale (tare, T). Then, each one was filled with $300 \mathrm{~g}$ of sand saturated with tap water, and the weight of the set gerbox + sand was gauged (initial weight, $\mathrm{W}_{\mathrm{i}}$ ). Finally, after the addition of the seeds, the gerboxes were weighed again (initial weight + seeds, $\mathrm{W}_{\mathrm{is}}$ ).

After those procedures, the gerboxes containing the seeds were divided into watering-frequency treatments, according to which the sand was re-moistened every 2 (T2), 4 (T4), 6 (T6), 8 (T8), 10 (T10), 12 (T12), 14 (T14), 16 (T16), and 34 (T34) days. Before the water was added to the substrate, seeds were removed, and the gerboxes were weighed (final weight, $\mathrm{W}_{\mathrm{f}}$ ). 
Then, the seeds were returned to their original gerbox, and the set was weighed again (final weight + seeds, $\mathrm{W}_{\mathrm{fs}}$ ). The difference between $\mathrm{W}_{\mathrm{i}}$ and $\mathrm{W}_{\mathrm{f}}$, corresponding to the amount of water lost during the period, was used to refill, so that the gerboxes could regain the initial weight, at the same sand initial saturation.

The water potential of the substrate (WP4) was analyzed at the beginning of the experiment, before the first watering, and at the end of the process. The evaluations were carried out before the water refill (except for the initial condition, assessed after sand saturation). At the end of the experiment, the substrate moisture was also evaluated through the oven method at $103 \pm 3{ }^{\circ} \mathrm{C}$ for $17 \mathrm{~h}$ (ISTA, 2017). Each treatment was composed of three replications, with nine seeds each.

After the usual experimental time (34 days), there were some still non-germinated seeds, probably due to the little remaining water in the sand. So, the substrate started being moistened whenever necessary, for 30 days, to check the viability of these seeds when water became available in the environment.

All the experiments were conducted in a completely randomized design. The results were subjected to analysis of variance (F-test at a 5\% probability level), and the means were compared by the Tukey's test (Santana and Ranal, 2004).

\section{Results and Discussion}

The water content of the analyzed specimens (Table 1) varied from $50.6 \%$ (E. brasiliensis) to $79.0 \%$ (E. pyriformis). Such high numbers are common among recalcitrant seeds, and they have been observed in many species of the genus Eugenia (Delgado and Barbedo, 2012). Also, values similar to the ones presented on this work were detected by other authors in $E$. brasiliensis and E. uniflora (Amador and Barbedo, 2015). On the other hand, Lamarca et al. (2011) and Amador and Barbedo (2011) found lower values in E. pyriformis.

As affirmed by Barbedo et al. (2013), variations in the water content of seeds of a particular species might indicate differences in the maturation stages at the moment when they were detached from the parent plant. This fact could even be responsible for the level of recalcitrance of the seeds. A new approach on recalcitrant seeds proposed by Barbedo (2018) considers these maturation disparities as the result of environmental factors, which can either anticipate or delay the moment of dispersion. Therefore, seeds with a high water content tend to be physiologically more immature, even if they were scattered naturally.

The evaluation of water potential $\left(\Psi_{w}\right)$ of the different PEG solutions (Figure 1) produced results close to the targeted values. This approximation became even more evident when the solutions were applied to the germination paper. The lower the water potential from $-4.5 \mathrm{MPa}$, the higher the difference between expected and real water potential because of the higher solution viscosity. According to Michel and Kaufmann (1973), viscosity exponentially increases with the PEG concentration due to structural changes in the polymer. Thus, the more negative the potential, the higher the PEG concentration and, consequently, the more viscous the solution.

In this study, the PEG solutions were always used in association with the germination paper. That being the case, the water potential measured when the solutions were applied directly to the substrate were equivalent to the expected values. On account of that, it can be assumed that the seeds were exposed to the targeted potential, so it was possible to obtain the intended gradient of water deficit.

E. involucrata seeds subjected to water potentials no lower than $-1.0 \mathrm{MPa}$ germinated at above $70 \%$. However, more negative potentials inhibited the phenomenon (Figure 2). In E. uniflora seeds, no difference in germination was noticed

Table 1. Water content (\%) and water potential (MPa) of seeds of E. brasiliensis, E. involucrata, E. pyriformis, and E. uniflora. Mean values and standard deviation are presented.

\begin{tabular}{lcc}
\hline \multicolumn{1}{c}{ Species } & Water content (\%) & $\begin{array}{c}\text { Water potential } \\
(\mathrm{MPa})\end{array}$ \\
\hline E. brasiliensis & $50.6 \pm 1.0$ & $-0.53 \pm 0.1$ \\
E. involucrata & $62.2 \pm 0.9$ & $-0.49 \pm 0.2$ \\
E. pyriformis & $79.0 \pm 0.9$ & $-0.47 \pm 0.1$ \\
E. uniflora & $57.4 \pm 1.4$ & $-0.55 \pm 0.1$ \\
\hline
\end{tabular}

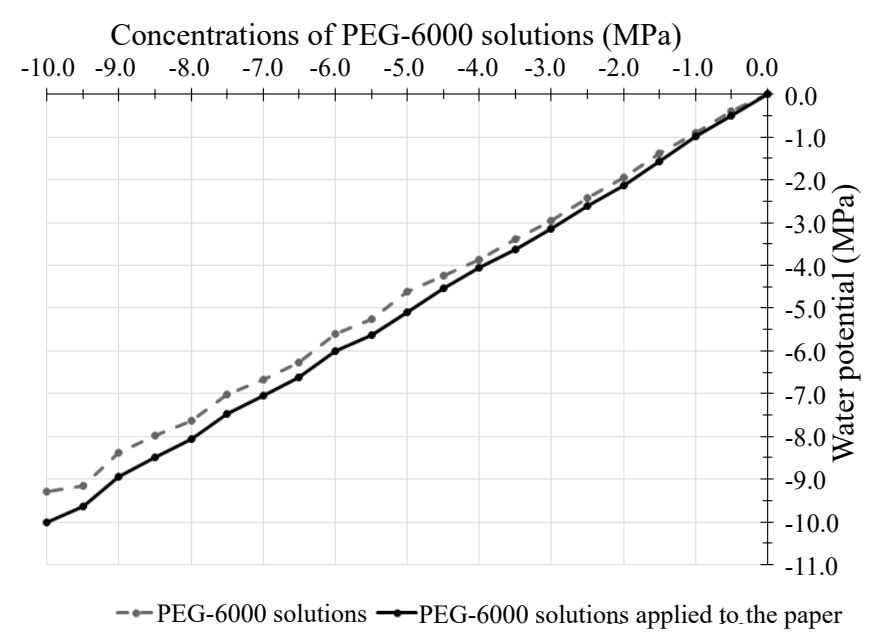

Figure 1. Real water potential of the PEG-6000 solutions (assessed by PEG solutions in a vial with and without germination paper, in a potentiameter) in contrast with the targeted water potential (i.e. the expected values according to PEG solution concentration). 
at 0.0 and $-0.5 \mathrm{MPa}$. Nevertheless, when they were exposed to -1.0 and $-1.5 \mathrm{MPa}$, the germination rate stayed between $39 \%$ and $61 \%$. Negative water potentials also compromised the germination and normal seedlings formation of $E$. brasiliensis and E. pyriformis. In the former, potentials above $-1.5 \mathrm{MPa}$ produced germination between $44 \%$ and $63 \%$; but only $19 \%$ of seedling formation was observed at $-0.5 \mathrm{MPa}$. In $E$. pyriformis, seed germination was close to zero at $-0.5 \mathrm{MPa}$, and no normal seedling was formed. No species germinated at potentials more negative than -1.5 MPa. Interestingly enough, this value corresponds to the permanent wilting point for several species (Taiz and Zeiger, 2004). It is important to emphasize that the germination criterion adopted by this work was based on the primary root growth, that is, on a process similar to what happens to adult plants.

The low germination percentages of E. pyriformis might

\section{E. brasiliensis}

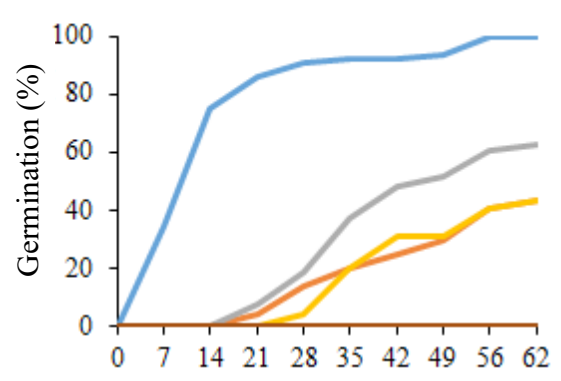

E. pyriformis

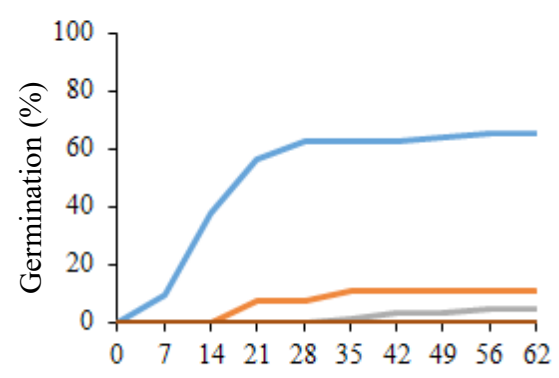

E. brasiliensis

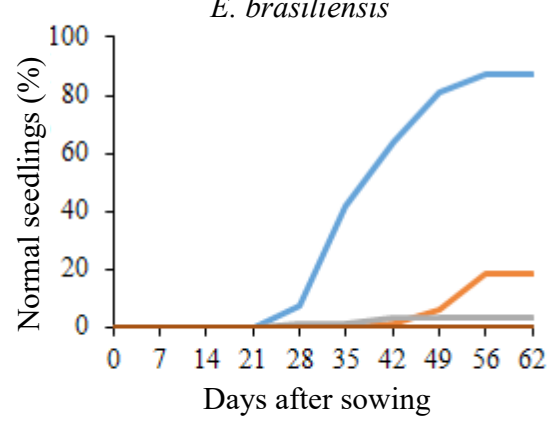

$-0.0 \mathrm{MPa} \quad-0.5 \mathrm{MPa}$
E. involucrata

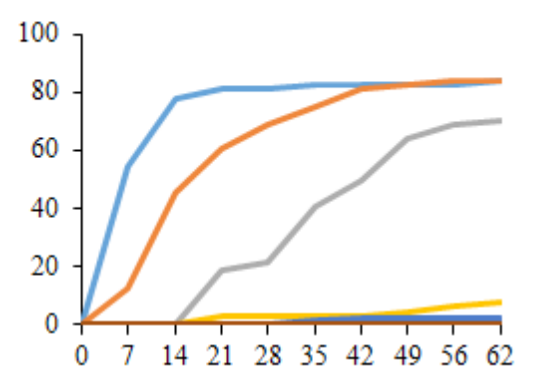

E. uniflora

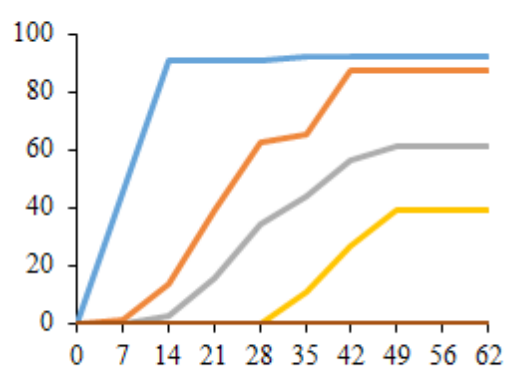

\begin{tabular}{c|cccc} 
& \multicolumn{4}{c}{ Germination (\%) } \\
\cline { 2 - 6 }$\Psi_{\mathrm{w}}$ & $E b$ & $E i$ & $E p$ & $E u$ \\
$(\mathrm{MPa})$ & & & & \\
\hline-0.0 & $100 \mathrm{a}$ & $84 \mathrm{a}$ & $66 \mathrm{a}$ & $92 \mathrm{a}$ \\
-0.5 & $44 \mathrm{~b}$ & $84 \mathrm{a}$ & $11 \mathrm{~b}$ & $88 \mathrm{a}$ \\
-1.0 & $63 \mathrm{~b}$ & $70 \mathrm{a}$ & $5 \mathrm{~b}$ & $61 \mathrm{~b}$ \\
-1.5 & $44 \mathrm{~b}$ & $8 \mathrm{~b}$ & $0 \mathrm{~b}$ & $39 \mathrm{~b}$ \\
-2.0 & $0 \mathrm{c}$ & $2 \mathrm{~b}$ & $0 \mathrm{~b}$ & $0 \mathrm{c}$ \\
-3.0 & $0 \mathrm{c}$ & $0 \mathrm{~b}$ & $0 \mathrm{~b}$ & $0 \mathrm{c}$ \\
-4.0 & $0 \mathrm{c}$ & $0 \mathrm{~b}$ & $0 \mathrm{~b}$ & $0 \mathrm{c}$ \\
-5.0 & $0 \mathrm{c}$ & $0 \mathrm{~b}$ & $0 \mathrm{~b}$ & $0 \mathrm{c}$ \\
\hline
\end{tabular}

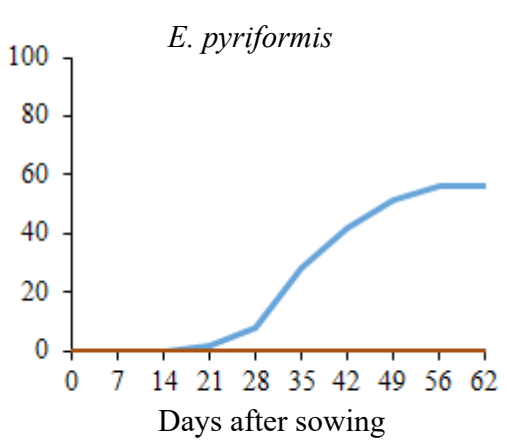

\begin{tabular}{|c|c|c|}
\hline \multirow[b]{2}{*}{$\begin{array}{c}\Psi_{\mathrm{w}} \\
(\mathrm{MPa})\end{array}$} & \multicolumn{2}{|c|}{ Jormal Seedlings (\%) } \\
\hline & $E b$ & $E p$ \\
\hline-0.0 & $88 \mathrm{a}$ & $56 \mathrm{a}$ \\
\hline-0.5 & $19 \mathrm{~b}$ & $0 \mathrm{~b}$ \\
\hline-1.0 & $3 \mathrm{c}$ & $\mathrm{Ob}$ \\
\hline-1.5 & $0 \mathrm{c}$ & $\mathrm{Ob}$ \\
\hline-2.0 & $0 \mathrm{c}$ & $\mathrm{Ob}$ \\
\hline-3.0 & $0 \mathrm{c}$ & $0 \mathrm{~b}$ \\
\hline-4.0 & $0 \mathrm{c}$ & $0 \mathrm{~b}$ \\
\hline-5.0 & $0 \mathrm{c}$ & $0 \mathrm{~b}$ \\
\hline
\end{tabular}

Figure 2. Germination of seeds of Eugenia brasiliensis, E.involucrata, E. pyriformis, and E. uniflora, and emerged normal seedlings of $E$. brasiliensis and E. pyriformis subjected to the following water stress regime: $-0.0,-0.5,-1.0,-1.5,-2.0$, $-3.0,-4.0$, and $-5.0 \mathrm{MPa}$. The tables contain the results of the last evaluation of analysis of variance of germination $(E$. brasiliensis $(\mathrm{Eb}): \mathrm{F}=59.12, \mathrm{p}<0.05 ;$ E. involucrata $(\mathrm{Ei}): \mathrm{F}=81.71, \mathrm{p}<0.05 ;$ E. pyriformis $(\mathrm{Ep}): \mathrm{F}=31.40, \mathrm{p}<0.05 ; E$. uniflora $(\mathrm{Eu}): \mathrm{F}=47.29, \mathrm{p}<0.05)$ and normal seedlings (E. brasiliensis $(\mathrm{Eb}): \mathrm{F}=127.06, \mathrm{p}<0.05 ;$ E. pyriformis $(\mathrm{Ep})$ : $\mathrm{F}=32.40, \mathrm{p}<0.05$ ). They also present the results of the Tukey's test at a $\%$ probability level (means followed by the same letter within each species do not differ from one another). 
indicate that the seeds from that particular crop were in a more immature state when dispersed. Underdeveloped seeds are usually more sensitive to under-optimum germination conditions (Barbedo et al., 2013).

As for the germination in water, in E. involucrata and E. uniflora the process was concentrated in the first 21 days, whereas in E. brasiliensis and E. pyriformis it prolonged to 56 and 35 days, respectively (Figure 3 ). Lower potentials caused the seeds to start sprouting later and for a more extended period. So, the more negative the water potential of the substrate was, the longer it took for seeds to emit the primary root, which dispersed the germination through time.

E. brasiliensis
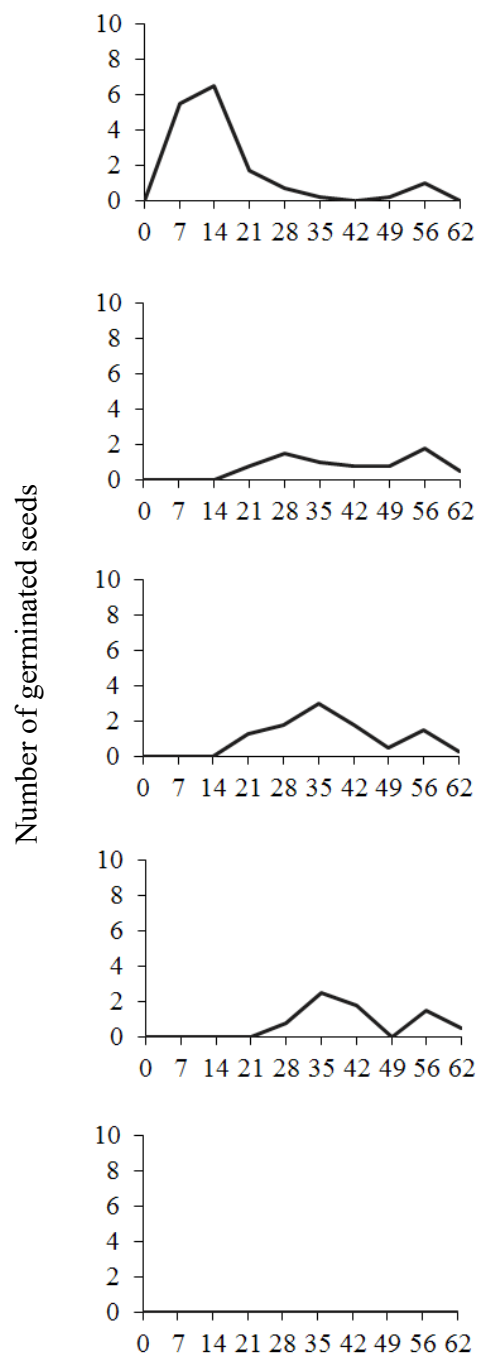

E. involucrata
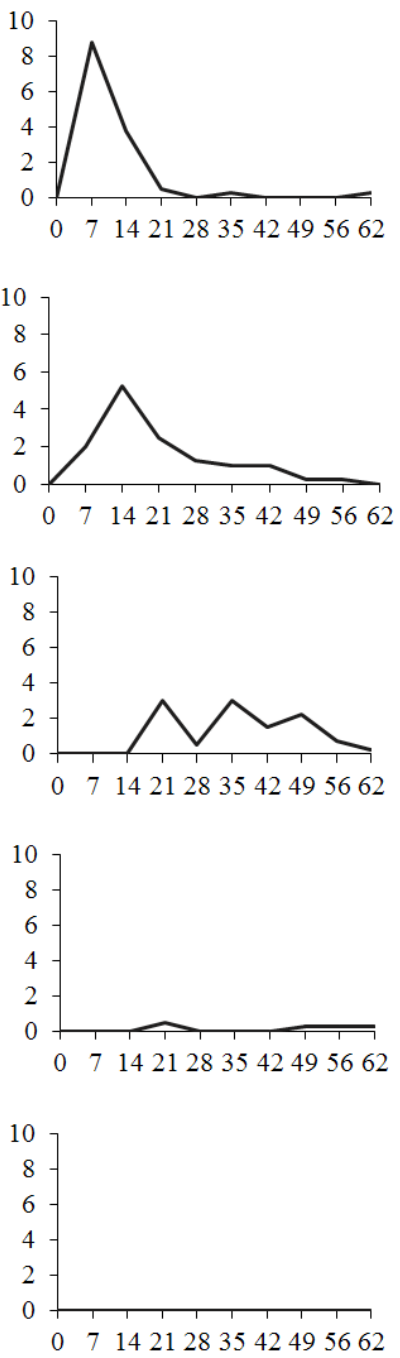

E. uniflora seeds (Group 2) that had been subjected to the water potentials of -2.0 and $-3.0 \mathrm{MPa}$ without sprouting exhibited a high germination rate, even reaching $100 \%$ when placed in a substrate moistened with water (Figure 4). Even the seeds that had been previously tested for more negative potentials $(-4.0$ and $-5.0 \mathrm{MPa})$ germinated above $50 \%$ when they were returned to the condition of $0.0 \mathrm{MPa}$. The restitution of the ability to produce normal seedlings in these conditions was observed for potential values as low as -4.0 $\mathrm{MPa}$, which proves that the seeds did not germinate during the water deficit treatments, but remained viable and capable of resuming the process once water was available. Similar
E. uniflora
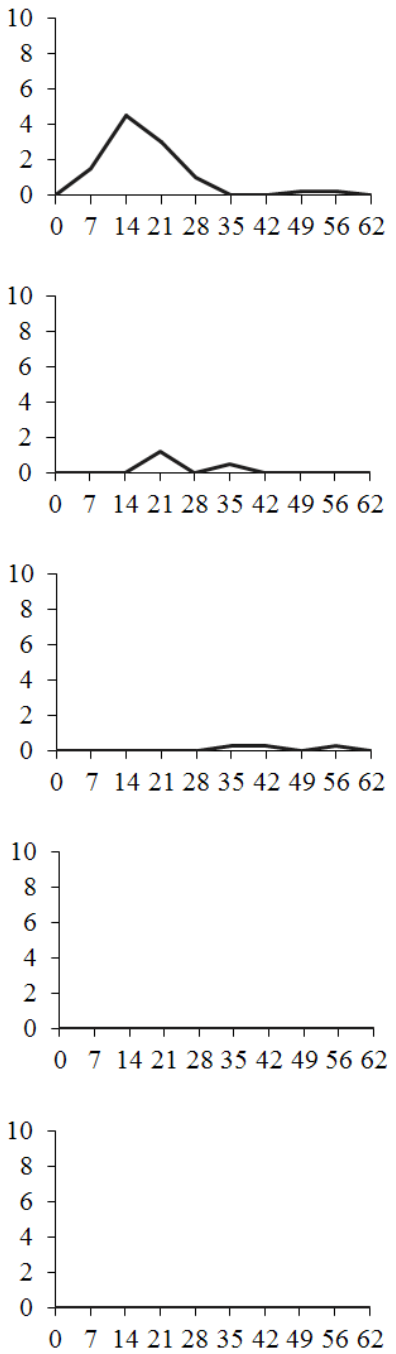
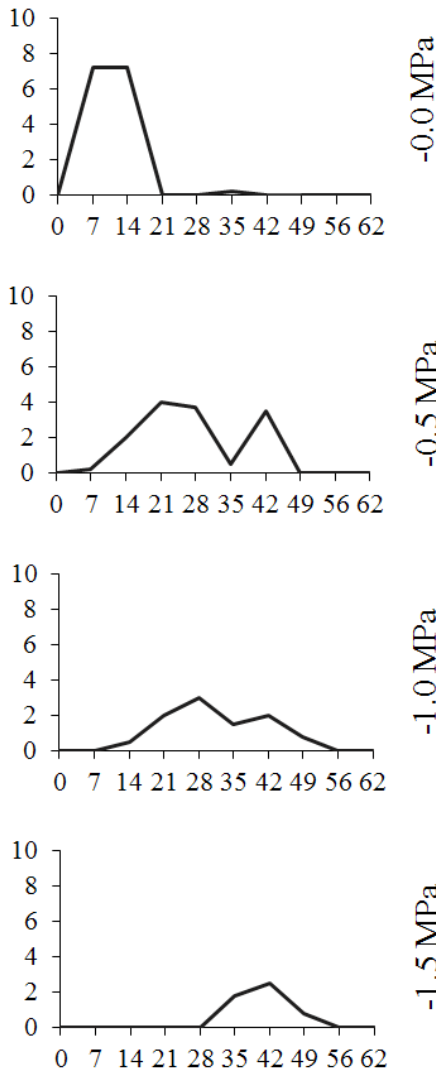

$\sum_{\substack{0 \\ 0}}^{\infty}$
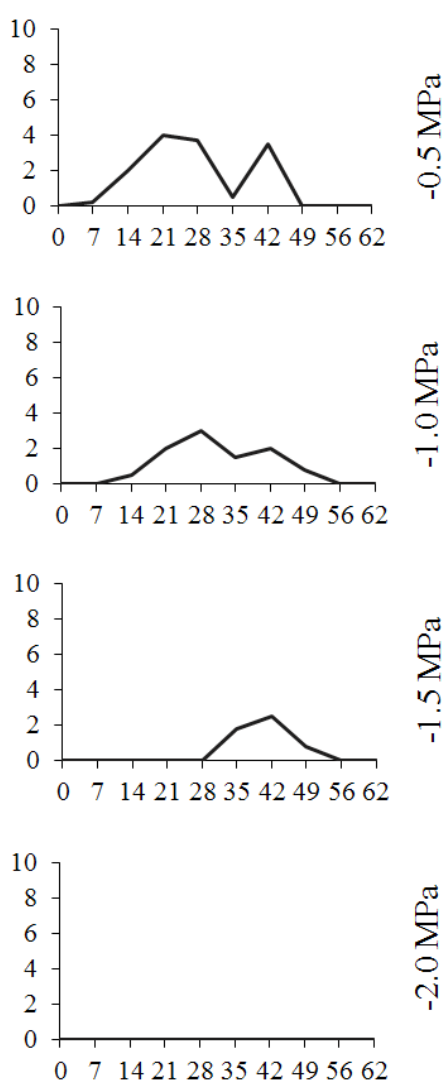

Days after sowing

Figure 3. Germination frequency over time of Eugenia brasiliensis, E. involucrata, E. pyriformis, and E. uniflora in the treatments -0.0 MPa, -0.5 $\mathrm{MPa},-1.0 \mathrm{MPa},-1.5 \mathrm{MPa}$, and -2.0 MPa. The values are expressed as the average number of germinated seeds. 
behavior was noticed in E. involucrata but, at potentials below -4.0 $\mathrm{MPa}$, the germination decreased, as well as the normal seedling formation.

E. brasiliensis seeds from the treatments at -2.0 and $-3.0 \mathrm{MPa}$ presented germination rates below $35 \%$ and $15 \%$, respectively, and those from the lower osmotic-potential solutions did not germinate at all when restored to a water-moistened substrate. On that account, it is possible to infer that the seeds had their viability compromised by the water-deficit treatments they were exposed to. Such outcome became more evident once $100 \%$ of the seeds from the control treatment germinated, and even some germination was observed at $-1.5 \mathrm{MPa}$.

As for E. pyriformis seeds, the ones that had not germinated in the PEG solutions above -2.0 MPa started to do so, and to produce normal seedlings, when water was provided. An example was the seeds treated at $-1.0 \mathrm{MPa}$, which showed germination close to $0 \%$ in the PEG solution, but were able to achieve $30 \%$ and produce normal seedlings once in water. Notwithstanding, considering that $40 \%$ of the lot was already dead by the beginning of the new trial, it is possible to affirm that those seeds, despite viable, had been extremely affected by the treatment. Besides, no species germinated when the seeds had been maintained in a PEG-moistened substrate for more than 30 days (Group 1).

In general, when variations in the substrate water availability occurred, regardless of the watering routine, the germination of Eugenia seeds reached more than $70 \%$

E. brasiliensis

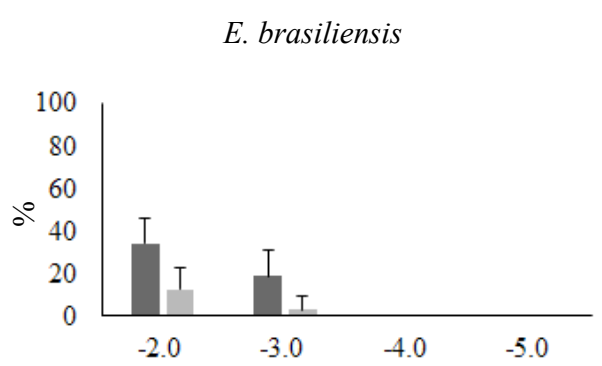

E. pyriformis

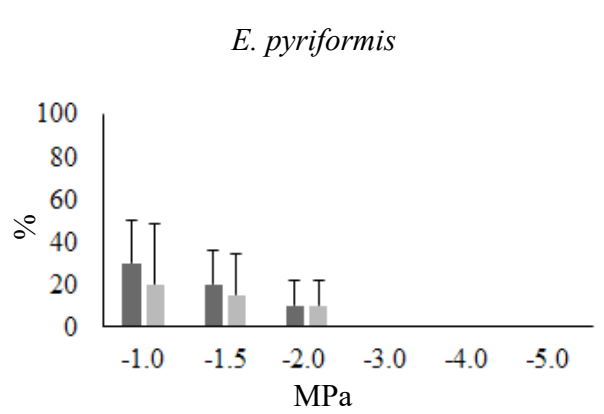

(Figure 5). In E. involucrata, E. pyriformis, and E. uniflora, no difference in germination was noticed among the treatments.

The large seeds of E. pyriformis germinated above $88 \%$ in all treatments, whereas the small ones sprouted at percentages from 40 to $50 \%$, in $\mathrm{T} 2$ and $\mathrm{T} 16$, and even at lower rates, in the other treatments. It is important to remark that the E. pyriformis seeds that were not sorted by size exhibited germination inferior to values observed in other studies. Lamarca et al. (2011) and Teixeira and Barbedo (2012), for example, obtained germination close to $100 \%$ for this species.

Considering that in the beginning of the experiment the substrate was saturated with water, it is possible to affirm that the variations in water availability did not stop or significantly compromise the germination of the seeds. However, normal seedling development was affected. So, it is likely that the seeds were able to use the initial water just to start germination. Besides that, in the cases which there was a longer interval between waterings, the substrate got drier, triggering protective mechanisms to prevent damages by water loss. These seeds are said to be recalcitrant (Delgado and Barbedo, 2012), meaning that, evolutionally, they did not invest in tolerance to desiccation to maintain their viability during the seasons of water shortage. On the other hand, they might have developed specific ways of preventing water loss in tissues that are vital for continuing with the proper seedling growth, when the water availability in the environment becomes favorable.

The frequency distribution over time (Figure 6) showed
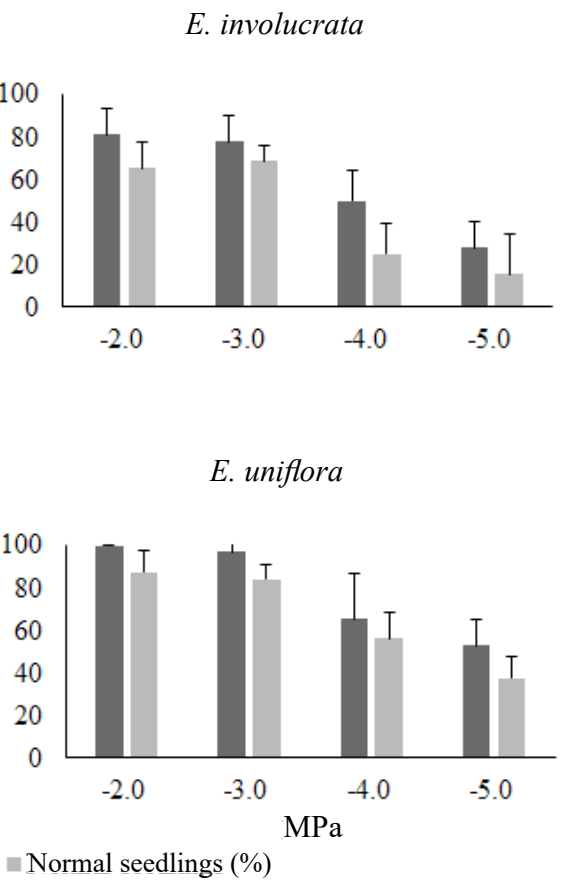

Figure 4. Germination in water and normal seedling emergence of Eugenia brasiliensis, E. involucrata, E. pyriformis, and E. uniflora from seeds previously submitted to different water deficit regimes. 
that Eugenia seeds endured up to 34 days of draught. On the other hand, they did not tolerate the excess of water very well. When the waterings were applied in alternated days, or even every four days, the germination results were less expressive, in both speed and percentage, than those produced by the seeds irrigated in turns of six or more days. Therefore, the mechanisms that preserve water in essential tissues were more efficient than the ones preventing water excess.

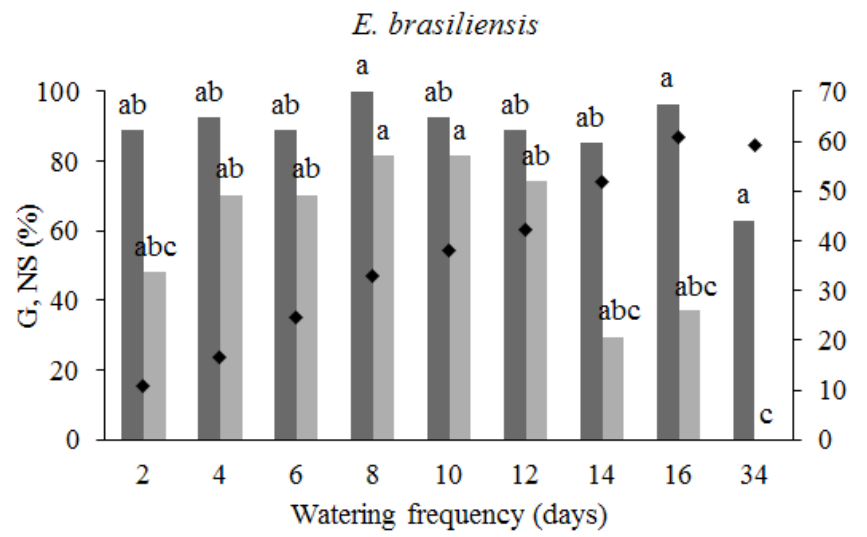

E. pyriformis (large)
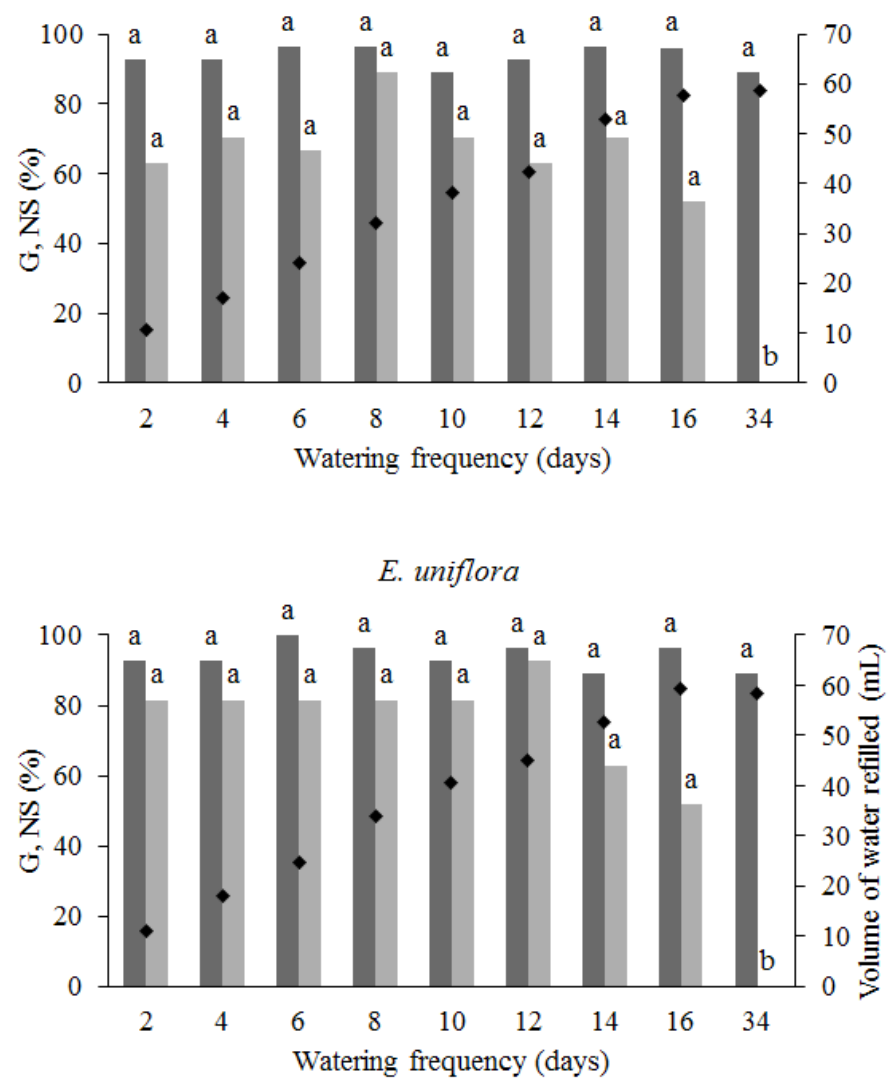

E. involucrata

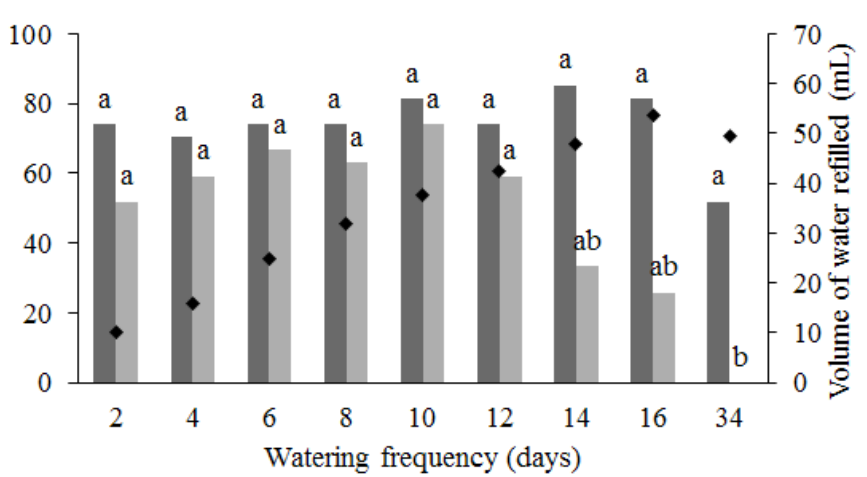

E. pyriformis (small)

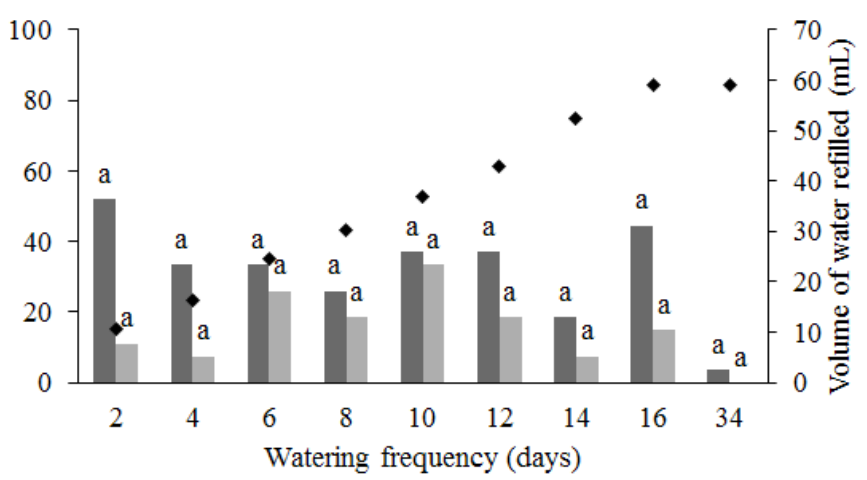

\author{
- Germination \\ - Normal Seedlings \\ - Water refill
}

Figure 5. Germination (G) and normal seedlings (NS) of Eugenia brasiliensis (G: $\mathrm{F}=2.81, \mathrm{p}<0.05$; NS: $\mathrm{F}=7.25, \mathrm{p}<0.05$ ), $E$. involucrata (G: $\mathrm{F}=1.20, \mathrm{p}<0.35691 ; \mathrm{NS}: \mathrm{F}=5.90, \mathrm{p}<0.05$ ), E. pyriformis (large seeds $\mathrm{G}$ : $\mathrm{F}=0.48, \mathrm{p}<0.85421 ; \mathrm{NS}$ : $\mathrm{F}=6.36$, $\mathrm{p}<0.05$; small seeds $\mathrm{G}$ : $\mathrm{F}=2.11, \mathrm{p}<0.08956$; NS: $\mathrm{F}=1.76, \mathrm{p}<0.15271$ ), and E. uniflora ( $\mathrm{G}: \mathrm{F}=0.37, \mathrm{p}<0.92012$; $\mathrm{NS}: \mathrm{F}=8.50$, $\mathrm{p}<0.05$ ), subjected to different regimes of water oscillation and substrate water refilling. Means followed by the same letter within each species do not differ from each other, according to the Tukey's test at a 5\% significance level. 
E. brasiliensis

E. involucrata

E. pyriformis

(large)
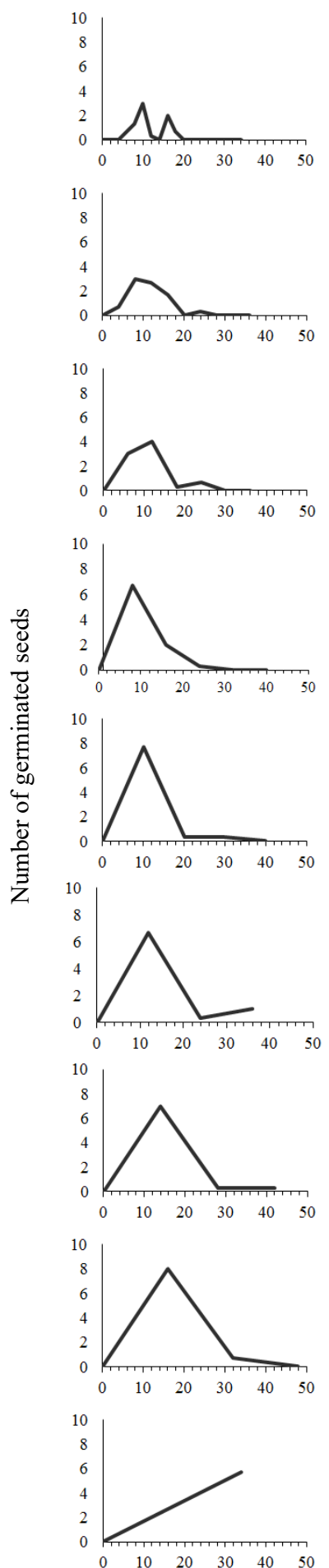
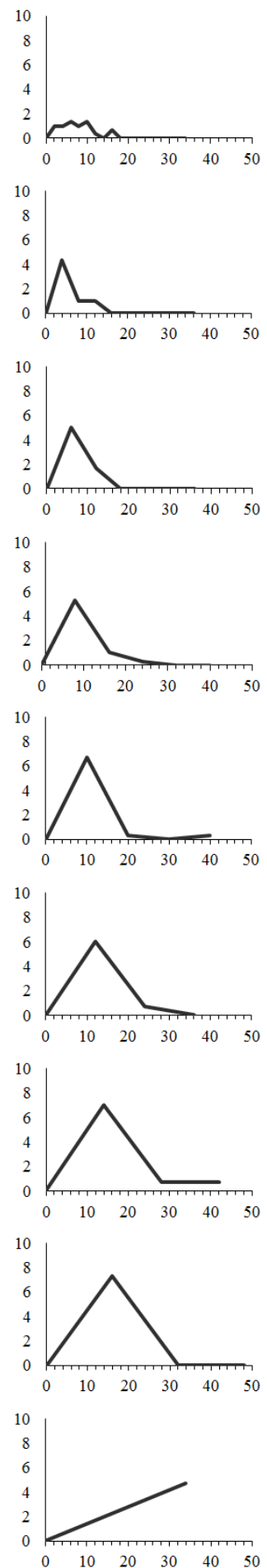
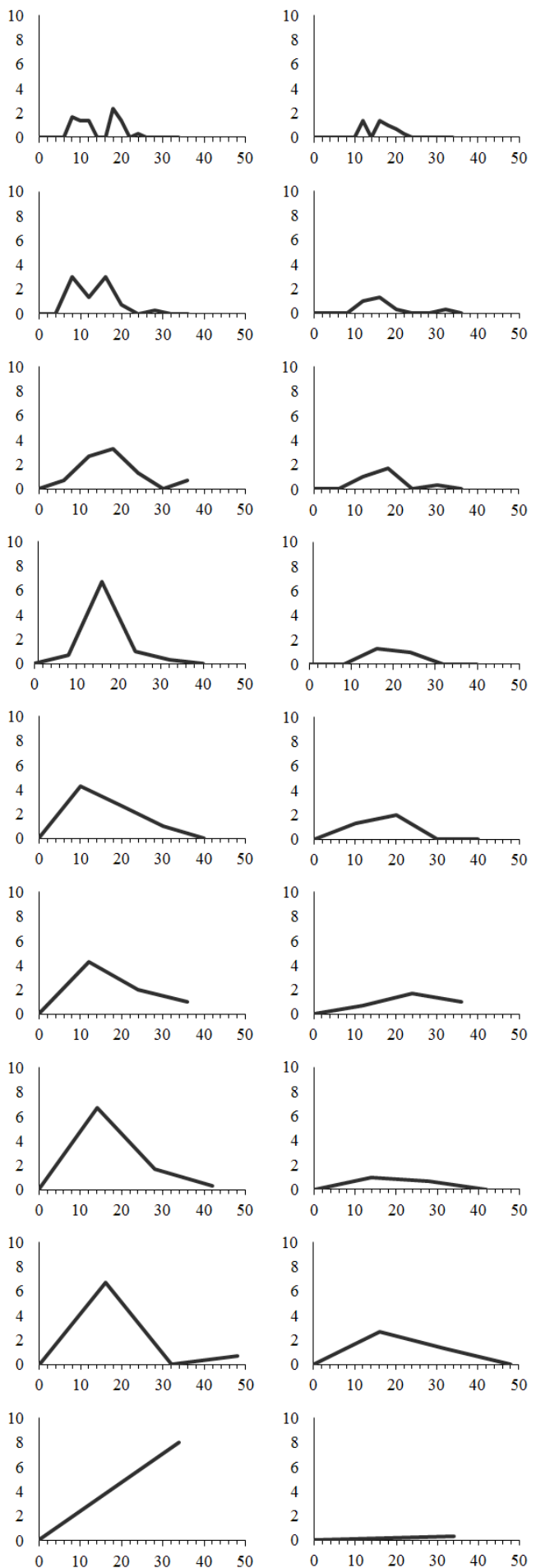
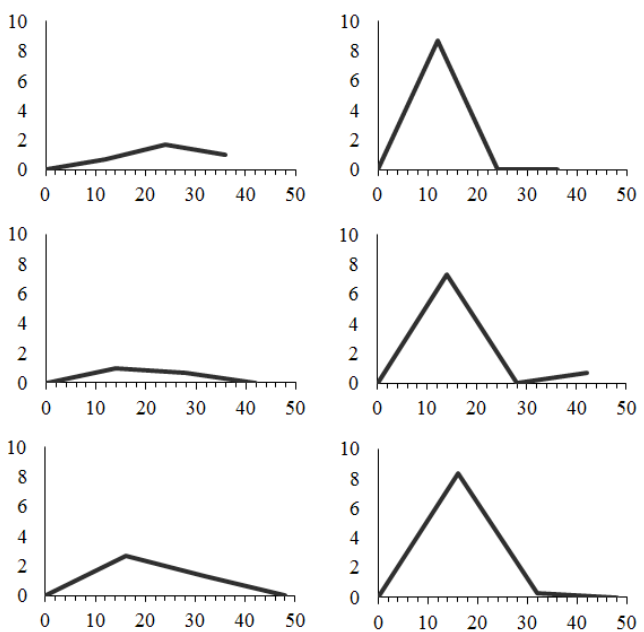

E. uniflora
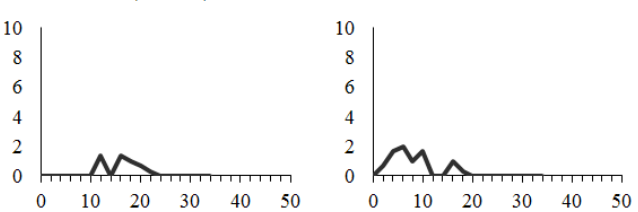

$\frac{n}{2}$
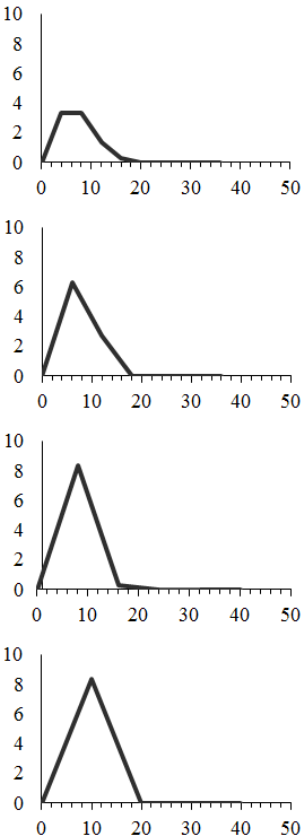

$\frac{\infty}{d}$

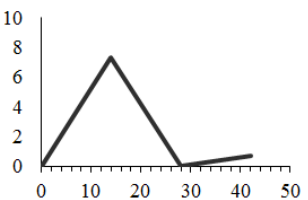

恶

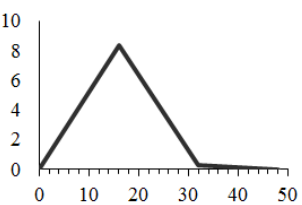

胥

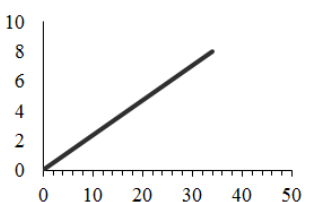

Days after sowing

Figure 6. Germination frequency over time of Eugenia brasiliensis, E. involucrata, E. pyriformis (large and small seeds), and E. uniflora under different water oscillation regimes (2, 4, 6, 8, 10, 12, 14, 16, and 34 days). The values are expressed as the average number of germinated seeds. 
The Eugenia seeds analyzed exhibited differences concerning the resistance to water deficits, which became evident not only because of the capacity of germinating at a broad spectrum of water potentials but also due to the survival of the plants in these conditions.

Studies developed by Delgado and Barbedo (2012) demonstrated that, considering the same water content, embryos from different Eugenia species showed high variation in the water potential, which could explain the behavioral differences perceived among them, regarding their endurance to desiccation and water content. Braz and Mattos (2010) noticed that the germination of $E$. umbelliflora decreased by $50 \%$ (in contrast with the control treatment), when the seeds were submitted to the water potential of $-0.37 \mathrm{MPa}$. On the other hand, the same seeds displayed low sensitiveness to drying. Therefore, Eugenia seeds are different not only in their level of tolerance to desiccation, but in the resistance to water-stress conditions as well.

In this study, the Eugenia seeds that could not germinate during the water-stress period were still able to keep the viability up to a certain water potential, then germinating and producing seedlings once water was again provided by the environment. This behavior suggests that, during the adverse condition, the seeds develop or activate some mechanism to prevent water loss by the embryo, keeping it alive, even if the seed itself is not capable of absorbing water.

Delgado and Barbedo (2012) investigated six species of Eugenia and noticed that, after drying, the values of water potential of the embryo were always higher than those of the seed tegument. Thus, it is likely that some active process was maintaining a minimum hydration level in the embryonic axis. Also, the imbalance of the water potential of distinct seed parts probably represents a strategy to reduce the risk of embryo death by desiccation.

The water potential that limits germination in some forest species, such as Bowdichia virgilioides, Ateleia glazioviana, and Anadenanthera colubrina (Silva et al., 2001; Rosa et al., 2005; Rego et al., 2011) is about -1.0 MPa. Therefore, Eugenia seeds can be considered very resistant to water stress. Calvi et al. (2017) verified that the seeds of E. stipitata were able to germinate when submerged in water, at various depths, and kept the viability for up to 12 months. So, it appears that Eugenia seeds can endure both water shortages and flooding conditions. They can germinate at a broad waterpotential spectrum and similarly adapt to various situations. This flexibility must be associated with the environmental conditions in which seeds develop, once the same occurs both inter and intraspecifically (Daws et al., 2004).

It is possible that the difference in tolerance to water stress observed in Eugenia seeds also applies to the seedlings. Calvi et al. (2017) found that seeds capable of growing seedlings under water had higher concentrations of glutathione disulfide (GSSG) than those that did not germinate when submerged. This result indicates that a flooding stress was more impactful on seedlings than on seeds.

Based on the differences in resistance to water deficit exhibited by the seeds of the Eugenia species analyzed, one can predict that E. uniflora and E. involucrata seeds would be less affected by water shortages at the beginning of germination, and that seeds would be able to resume the germination process once water becomes available. E. brasiliensis seeds, in their turn, would guarantee the development of some specimens, as long as the period of scarcity was not too long.

\section{Conclusions}

Seeds of Eugenia spp. showed interspecific variations regarding the resistance to water deficits, both in intensity and duration. However, in all the species analyzed, the attempt to preserve the vital tissues was clear, thus allowing the development of seedlings and the propagation of the species.

\section{Acknowledgments}

The authors express their gratitude to Coordenação de Aperfeiçoamento de Pessoal de Nivel Superior (CAPES), for the scholarship granted to the first author; to the program of Post-graduation in Plant Biodiversity and Environment of the Institute of Botany, for the opportunity given to the first author; and to Fundação de Amparo à Pesquisa do Estado de São Paulo (FAPESP), for the financial support given to this project (Prot. 2017/50341-0).

\section{References}

AMADOR, T.S.; BARBEDO, C.J. Potencial de inibição da regeneração de raízes e plântulas em sementes germinantes de Eugenia pyriformis. Pesquisa Agropecuária Brasileira, v.46, n.8, p.814-821, 2011. http://www.scielo.br/pdf/pab/v46n8/05.pdf

AMADOR, T.S.; BARBEDO, C.J. Germination inhibits the growth of new roots and seedlings in Eugenia uniflora and Eugenia brasiliensis. Journal of Seed Science, v.37, n.3, p.241-247, 2015. http://www.scielo.br/pdf/jss/v37n3/2317-1537-jss-37-032317_1545v37n3150595.pdf

BARBEDO, C.J.; CENTENO, D.C.; RIBEIRO, R.C.L.F. Do recalcitrant seeds really exist? Hoehnea, v.40, n.4, p.583-593, 2013. http://www.scielo.br/pdf/hoehnea/v40n4/01.pdf 
BARBEDO, C.J. A new approach towards the so-called recalcitrant seeds. Journal of Seed Science, v.40, n.3, p.221-236, 2018. http:// www.scielo.br/pdf/jss/v40n3/2317-1545-jss-40-03-221.pdf

BRAZ, M.I.G.; MATTOS, E.A. Seed dispersal phenology and germination characteristics of a drought-prone vegetation in Southeastern Brazil. Biotropica, v.42, n.3, p.327-335, 2010. https:// onlinelibrary.wiley.com/doi/pdf/10.1111/j.1744-7429.2009.00602.x

CALVI, G.P.; ANJOS, A.M.G.; KRANNER, I.; PRITCHARD, H.W.; FERRAZ, I.D.K. Exceptional flooding tolerance in the totipotent recalcitrantseeds ofEugeniastiptata.SeedScienceResearch,v.27,p.121130, 2017. https://www.cambridge.org/core/services/aop-cambridgecore/content/view/BF0E93FE340A3F6181B9437EBE751D81/ S0960258517000125a.pdf/exceptional_flooding_tolerance_in_the_ totipotent_recalcitrant_seeds_of_eugenia_stipitata.pdf

DAWS, M.I.; LYDALL, E.; CHMIELARZ, P.; LEPRINCE, O.; MATTHEWS, S.; THANOS, C.A.; PRITCHARD, H. Developmental heat sum influences recalcitrant seed traists in Aesaculus hippocastaneum across Europe. New Phytologist, v.162, n.1, p.157-166, 2004. https://nph. onlinelibrary.wiley.com/doi/epdf/10.1111/j.1469-8137.2004.01012.x

DELGADO, L.F.; BARBEDO, C.J. Water potential and viability of seeds of Eugenia (Myrtaceae), a tropical tree species, based upon different levels of drying. Brazilian Archives of Biology and Technology, v.55, n.4, p.583-590, 2012. http://www.scielo.br/pdf/ babt/v55n4/a14v55n4.pdf

FANTI, S.C.; PEREZ, S.C.J.G.A. Processo germinativo de sementes de paineira sob estresses hídrico e salino. Pesquisa Agropecuária Brasileira, v.39, n.9, p.903-909, 2004. http://www.scielo.br/pdf/pab/ v39n9/22034.pdf

ISTA. International Rules for Seed Testing. The International Seed Testing Association, Bassersdorf, Switzerland. 2017. 296p. http:// www.ingentaconnect.com/content/ista/rules/2017/00002017/00000 001 ;jsessionid=a70srcbaui4q5.x-ic-live-02

JALEEL, C.A.; MANIVANNAN, P.; WAHID, A.; FAROOQ, M.; AL-JUBURI, H.J.; OMASUNDARAM, R.; PANNEERSELVAM, R. Drought stress in plants: a review on morphological characteristics and pigments composition. International Journal of Agriculture and Biology, n.11, n.1, p.100-105, 2009. https://pdfs.semanticscholar. org/fc62/ad94f99b818ee7f9aca6d879b434b04ba609.pdf

LAMARCA, E.V.; SILVA, C.V.; BARBEDO, C.J. Limites térmicos para a germinação em função da origem de sementes de espécies de Eugenia (Myrtaceae) nativas do Brasil. Acta Botanica Brasilica, v.25, n.2, p.293300, 2011. http://www.scielo.br/pdf/abb/v25n2/a05v25n2.pdf
MICHEL, B.E.; KAUFMANN, M.R. The osmotic potential of polyethylene glycol 6000. Plant Physiology, v.51, p.914-916, 1973. http://www.plantphysiol.org/content/plantphysiol/51/5/914.full.pdf

REGO, S.S.; FERREIRA, M.M.; NOGUEIRA, A.C.; GROSSI, F.; SOUSA, R.K.; BRONDANI, G.E.; ARAUJO, M.A.; SILVA, A.L.L. Estresse hídrico e salino na germinação de sementes de Anadenanthera colubrina (Veloso) Brenan. Journal of Biotechnology and Biodiversity, v.2, n.4, p.37-42, 2011. https://sistemas.uft.edu.br/ periodicos/index.php/JBB/article/view/212/146

ROSA, L.S.; FELIPPI, M.; NOGUEIRA, A.C.; GROSSI, F. Avaliação da germinação sob diferentes potenciais osmóticos e caracterização morfológica da semente e plântula de Ateleia glazioviana Bail (Timbó). Revista Cerne, v.11, n.3, p.306-314, 2005. http://cerne.ufla. br/site/index.php/CERNE/article/download/446/385/

SANTANA, D.G.; RANAL, M.A. Análise da germinação: um enfoque estatístico. Brasília: UnB, 2004. 247p.

SANTOS, A.R.F.; SILVA-MANN, R.; FERREIRA, R.A. Restrição hídrica em sementes de jenipapo (Genipa americana L.). Revista Árvore, v.35, n.2, p.213-220, 2011. http://www.scielo.br/pdf/rarv/ $\mathrm{v} 35 \mathrm{n} 2 / \mathrm{a} 06 \mathrm{v} 35 \mathrm{n} 2$.pdf

SCHMEDA-HIRSCHMANN, G.; THEODULOZ, C.; FRANCO, L.; FERRO, E.B.; ARIAS, A.R. Preliminary pharmacological studies on Eugenia uniflora leaves: xanthine oxidase inhibitory activity. Journal of Ethnopharmacology, v.21, p.183-186, 1987. https://pdfs.semanticscholar. org/9166/bb66a2fb7b7397e2813afa97a4529b0950be.pdf

SILVA, L.M.M.; AGUIAR, I.B.; RODRIGUES, T.J.D. Seed germination of Bowdichia virgilioides Kunth, under water stress. Revista Brasileira de Engenharia Agrícola e Ambiental, v.5, n.1, p.115-118, 2001. http://www.scielo.br/pdf/rbeaa/v5n1/v5n1a21.pdf

STEFANELLO, R.; GARCIA, D.C.; MENEZES, N.L.; MUNIZ, M.F.B.; WRASSE, C.F. Efeito da luz, temperatura e estresse hídrico no potencial fisiológico de sementes de funcho. Revista Brasileira de Sementes, v.28, n.2, p.135-141, 2006. http://www.scielo.br/pdf/ $\mathrm{rbs} / \mathrm{v} 28 \mathrm{n} 2 / \mathrm{a} 18 \mathrm{v} 28 \mathrm{n} 2 . \mathrm{pdf}$

TAIZ, L.; ZEIGER, E. Fisiologia Vegetal. Porto Alegre: Artmed, 2004. 719p.

TEIXEIRA, C.C.; BARBEDO, C.J. The development of seedlings from fragments of monoembryonic seeds as an important survival strategy for Eugenia (Myrtaceae) tree species. Trees, v.26, n.3, p.1069-1077, 2012. https://link.springer.com/article/10.1007\%2Fs00468-011-0648-5 